\title{
Biogas Production Using Slaughterhouse Wastewater Co-digested with Domestic Sludge
}

\author{
Salah S.B. Dababat, Hafez Q. Shaheen \\ Department of Civil Engineering, Faculty of Engineering and Information Technology, An-Najah National \\ University, Nablus, West Bank, Palestine \\ E-mail: Shaheen@najah.edu; Salahdaraghmah@hotmail.com
}

Received: 28 September 2018; Accepted: 9 November 2018; Available online: 25 January 2019

\begin{abstract}
The paper investigates producing biogas using Co-digestion of slaughterhouse wastewater (SHW) with primary sludge (PS). Lab experiments were executed at mesophilic condition $\left(35 \pm 2^{\circ} \mathrm{C}\right)$. Two experiments were performed; the first in a $2000 \mathrm{ml}$ vessel and the second in $600 \mathrm{ml}$ serum bottles, both to mimic batch bioreactors. Among others, acidity ( $\mathrm{pH}$ ), alkalinity (ALK), and volatile fatty acids (VFA) were measured before and after the digestion process. The daily biogas and methane production were also measured. The experiments showed that Co-digestion achieved maximum biogas yield at $499.8 \mathrm{Nml}$ Biogas $/ \mathrm{g}$ VS fed. The biogas yield for PS and SHW were $411.5 \mathrm{Nml}$ biogas /g VS fed and $433.8 \mathrm{Nml}$ biogas /g VS fed respectively. $\mathrm{CH}_{4}$ yield from the Co-digestion was the highest compared to digest SHW separately. This proves the occurrence of inhibition in methanogenesis activity. The VFA final concentration was higher than the initial concentration for digest SHW.
\end{abstract}

Keywords: Anaerobic digestion; Biogas; Co-digestion; Domestic sludge; Methane; Slaughterhouse wastewater.

\section{Introduction}

Anaerobic Digestion is a process of decomposition of organic materials, by which organic compounds are broken down to simple components specifically under anaerobic conditions to produce methane $\left(\mathrm{CH}_{4}\right)$ and carbon dioxide $\left(\mathrm{CO}_{2}\right)$ and other traces [1].

The remaining fraction from the digested material after degradation process is called digestate. It is rich in nutrients; nitrogen $(\mathrm{N})$, phosphorus $(\mathrm{P})$, and potassium $(\mathrm{K})$ [2]. Digestate is beneficial for the soil and is used as a fertilizer and soil improvement in farming and for gardens.

Biogas is an energy source. It burns cleanly and produces less carbon dioxide than fossil fuel. It comprises mainly from methane and carbon dioxide with traces of nitrogen, sulfuric acid, and ammonia [3]. Efforts are in progress to expand the utilization of organic waste to produce biogas. There are many applications for biogas such as generation of electricity and vehicle fuel [4].

Several literatures studied the implementation of anaerobic digestion to treat slaughterhouse wastes. Other literatures reported using these wastes in Co-digestion process. Bayr et al. 2012, studied the effect of temperature on biogas production in semi-continuous system for Co-digestion of rendering and slaughterhouse wastes. In their study the relation between methane yield and temperature was obtained. In mesophilic system, the obtained methane yield was $720 \mathrm{ml} \mathrm{CH} / \mathrm{g}$ VS (added) when the organic loading rates was 1.0 and $1.5 \mathrm{~g} \mathrm{VS} / \mathrm{L} . \mathrm{d}$. While in case of thermophilic system, lower organic loading rate was selected and the process faced operation problems after 1.5 hydraulic retention time. This is due to accumulation of ammonia and VFA in addition to long chain fatty acids within the digester slurry [5].

Serrano et al. 2013, studied the biogas production from Co-digestion sewage sludge with orange peel in mesophilic range at $35^{\circ} \mathrm{C}$. Methane production got enhanced when Co-digestion was used comparing with methane production from digest sewage and peel separately. The methane production was recorded around $165 \mathrm{ml} \mathrm{CH} / \mathrm{g}$ VS [6].

\section{The experiment}

Biogas production from anaerobic digestion was measured using a small closed reactor as batch system. Two sets of experiments were performed with different batch lab scale reactors; the first was performed in a $2000 \mathrm{ml}$ vessel and the second was in $600 \mathrm{ml}$ serum bottles both to mimic batch bioreactors. Totally, 12 batch reactors were used. The first 5 have volume of $2000 \mathrm{ml}$ made from an autoclave glass and the rest have volume of $600 \mathrm{ml}$ made 
from serum bottle sealed by septum rubber and aluminum cap. To measure the volume of the produced biogas, water displacement method was used (Figure 1).

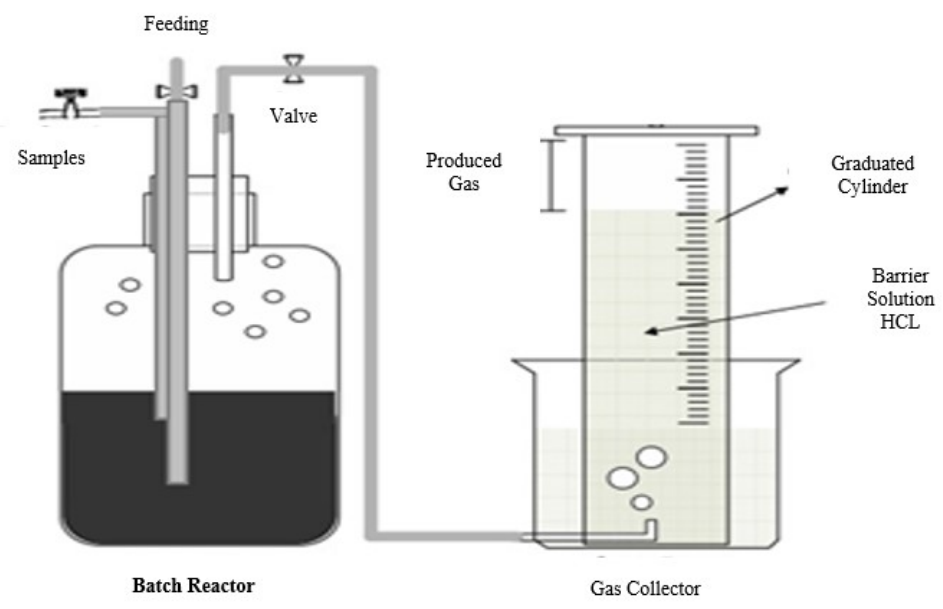

Figure 1. Gas measuring unit

Most important is the presence of the microorganisms that are responsible for digestion process. Anaerobic decomposition condition have been provided by presenting the microorganisms that are required for digestion. Each reactor was inoculated with adequate volume from inoculum sample. The inoculum sample was brought from a full-scale anaerobic digester, which is operated at WWTP Nablus-West.

The inoculum sample was transported in 3 and 10 liters polyethylene containers. Drop in inoculum temperature was considerate during the transportation by using a Styrofoam Box and cooler box, with hot water bottles to keep the temperature within the acceptable range at $35^{\circ} \mathrm{C}$.

Several trials have been conducted to keep the inoculum active without affecting microbial population during the seeding process. Pure nitrogen gas $\left(\mathrm{N}_{2}\right)$ was used to find oxygen free environment. Gloves were used to detect gas formation. The bottles were kept in an incubator at $35 \pm 2{ }^{\circ} \mathrm{C}$ for few days (Figure 2).

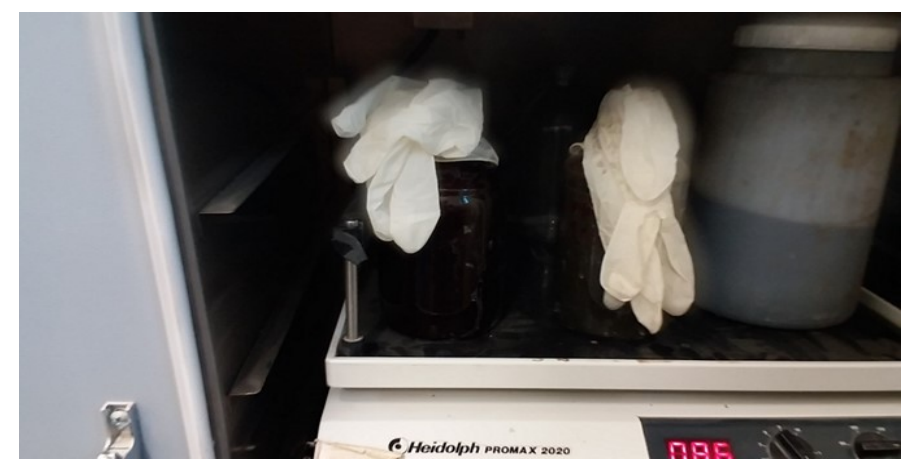

Figure 2. Investigation of inoculum activity

The first sludge sample was taken from the mixing tank at WWTP Nablus-West. A second sludge sample was taken from the primary settling tank. The samples were transported to the laboratory in polyethylene containers and in a cooler box, and then stored at $4{ }^{\circ} \mathrm{C}$ for one day before testing.

Slaughterhouse Wastewater samples were collected from Nablus municipality slaughterhouse, where 12 fresh samples were mixed together in polyethylene container. The composite sample was transported and kept at $4^{\circ} \mathrm{C}$ for one day. The SHW sample reflects the slaughtering practices and was taken from the stream discharged inside the slaughter room and contains water, blood, and pieces of meat and fat from washing the slaughtered. The feed substrates were prepared according to specific mixing ratios. Table 1 presents the raw characteristics of the tested substrates.

Since production of biogas from domestic sludge is a proven technology, the Co-digestion sample for the second experiment has been prepared to have at least $50 \%$ of its volume from domestic sludge. Tables 2 and 3 list the proportions of substrates in all reactors for the experiments. 
Figure 3 illustrates that ambient air exists in the digester headspace containing oxygen $\left(\mathrm{O}_{2}\right)$. This is not perfectly anaerobic and it is impossible for anaerobic bacteria to survive long enough to produce significant gas. To overcome this problem, $\mathrm{N}_{2}$ gas was used for flushing the reactors headspaces after feeding.

Table 1. Characteristics of raw tested substrate

\begin{tabular}{llll}
\hline Parameters & PS & SHW & Inoculum \\
\hline $\mathrm{pH}$ & 5.77 & 6.70 & 7.18 \\
$\mathrm{TS}(\mathrm{g} / \mathrm{L})$ & $18 \pm 0.11$ & $7.2 \pm 0.16$ & $21.6 \pm 0.18$ \\
$\mathrm{VS}(\mathrm{g} / \mathrm{L})$ & $14.51 \pm 0.13$ & $6.46 \pm 0.17$ & $11.45 \pm 0.11$ \\
$\mathrm{COD}(\mathrm{mg} / \mathrm{L})$ & 16400 & 8500 & 16200 \\
$\mathrm{ALK}(\mathrm{mg} \mathrm{CaCO} / \mathrm{L})$ & 3450 & 1150 & 3700 \\
$\mathrm{VFA}\left(\mathrm{mg} \mathrm{H}_{3} \mathrm{COOH} / \mathrm{L}\right)$ & 2332 & 340 & 340 \\
\hline
\end{tabular}

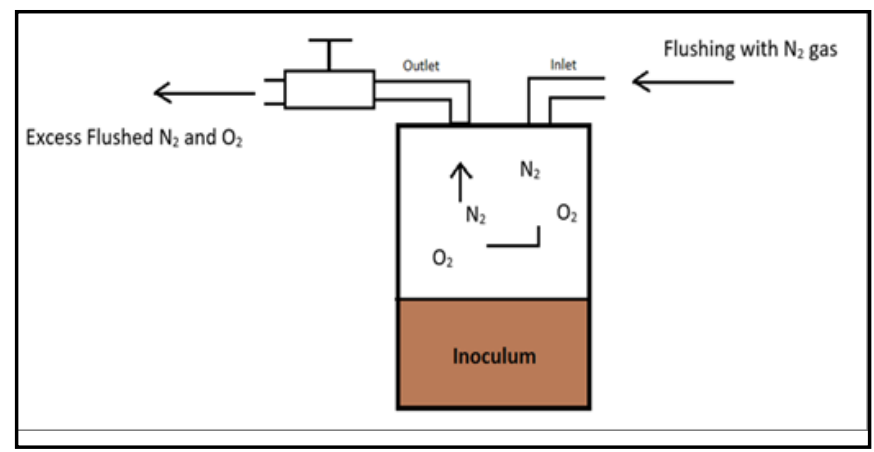

Figure 3. Illustration of $\mathrm{N}_{2}$ gas flushing

Table 2. Proportions of substrates in the first experiment

\begin{tabular}{|c|c|c|c|c|}
\hline \multirow[t]{2}{*}{ Reactor } & \multicolumn{2}{|c|}{ \% Mixture volume } & \multirow{2}{*}{$\begin{array}{c}\text { \% Inoculum volume } \\
\text { I }\end{array}$} & \multirow{2}{*}{$\begin{array}{c}\text { \% Headspace } \\
\text { Headspace }\end{array}$} \\
\hline & $\mathrm{SS}$ & SHW & & \\
\hline D1 & $0 \%$ & $0 \%$ & $20 \%$ & $80 \%$ \\
\hline D2 & $100 \%$ & $0 \%$ & $20 \%$ & $30 \%$ \\
\hline D3 & $0 \%$ & $100 \%$ & $20 \%$ & $30 \%$ \\
\hline D4 & $75 \%$ & $25 \%$ & $20 \%$ & $30 \%$ \\
\hline D5 & $25 \%$ & $75 \%$ & $20 \%$ & $30 \%$ \\
\hline
\end{tabular}

Table 3. Proportions of substrates in the second experiment

\begin{tabular}{lcccc}
\hline \multirow{2}{*}{ Reactor } & \multirow{2}{*}{ C Contribution in mixture (\% volume) } & & Inoculum: Substrate ratio (based on VS) \\
\cline { 2 - 3 } & PS & SHW & & I : S \\
\hline D-PS & & $0 \%$ & $2: 1$ \\
\hline D1 & $100 \%$ & $0 \%$ & $2: 1$ \\
D2 & $100 \%$ & & \\
\hline D-SHW & & $100 \%$ & $2: 1$ \\
\hline D1 & $0 \%$ & $100 \%$ & $2: 1$ \\
\hline D2 & $0 \%$ & & $2: 1$ \\
\hline D-CO & & $50 \%$ & $2: 1$ \\
\hline D1 & $50 \%$ & $50 \%$ & \\
\hline D2 & $50 \%$ & $0 \%$ & \\
\hline
\end{tabular}

The physical and chemical parameters for the raw samples and the digesters contents have been analyzed before and after digestion process. The $\mathrm{pH}$ values for all substrates were analyzed according to standard methods for examination water and wastewater [7]. Accuracy limits reported for $\mathrm{pH}$ are \pm 0.01 unit. The chemical oxygen 
demand (COD) has been considered as a measurement for organic compound and was determined using HANNAHI 83214 Multi-parameter bench photometer. Organic acids and buffer capacity have been determined by using Nordmann method of 1977.

The produced biogas was collected by water displacement method using Hydrochloric acid (HCl) solution with $\mathrm{pH}$ lower than 2. Biogas samples were taken by syringe from the collected gas and was injected into multi gas detector (portable biogas analyzer) to determine the percent of methane within the produced biogas. Total biogas and methane volume for each digester were calculated. The volume of the produced biogas has been measured daily and ambient temperature was recorded. The measured volumes for both methane and biogas have been presented at standard temperature and pressure; $0{ }^{\circ} \mathrm{C}$ and $101.325 \mathrm{kPa}$; Figure 4 is the biogas measurement unit.

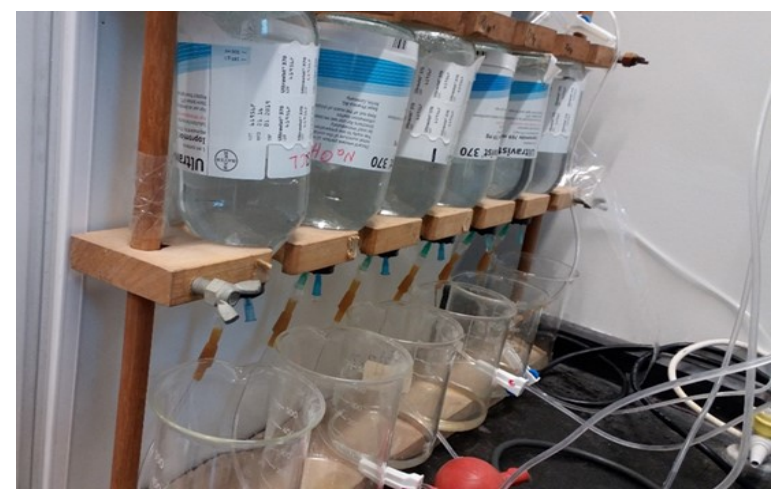

Figure 4. Biogas measurement unit

\section{Results and discussion}

The first experiment was cancelled since no significant gas production was produced until the fifth week that is a too long period for gas formation. Inoculum was added at the beginning specifically to avoid this long period.

The system was acclimating itself trying to reach the start-up phase. This prolonged lag phase could be caused due to inhibition occurred in the bacteria cultures that were provided through the inoculums. The number of bacteria was inappropriate and led to a defect in its functionality. Practically, inoculum to substrate ratio (I/S) was lower than 1, therefore overloading took place which is the main reason for the problem.

$\mathrm{I} / \mathrm{S}$ ratio is the ratio between grams of inoculum (bacteria cell) to grams of feed. It has impact on the occurrence of the lag phase (extracellular hydrolysis), methanogenesis, VS reduction, and resistance of the microorganisms for the inhibitory impacts during digestion process. Literatures consider the $\mathrm{I} / \mathrm{S}$ as the major parameter that affects the digestion process [8]. It is responsible for the presence of the groups of microorganisms that are needed for carrying out the digestion process. Lower I/S can cause accumulation of VFAs and lead to inhibition in methanogenesis function.

For a stable digestion system, I/S ratio is a major parameter and is suggested to be more than 2 (based on VS). Therefore, anaerobic reactors must have high microbial activity to work at stable conditions. I/S ratio was increased in the second experiment.

\subsection{Gas yield}

Comparisons have been made based on volume of gas from each reactor. The Biogas yield is expressed as a function of the VS that was added into the digestion system represented as Normalized $\mathrm{mL}$ of Biogas $/ \mathrm{g}$ VS added. The methane yield is formulated as a function of the VS that was added into the digestion system expressed as Normalized $\mathrm{mL}$ of methane/g VS added.

It can be revealed that the biogas production from all tested substrates started at a higher production rate (early peak) and the majority of the biogas was produced in the first days. This was due to the characteristics, activity and intensity of the inoculums; net accumulative of biogas yield for each tested substrate is depicted in Figure 5 .

The lowest biogas yield at $411.5 \mathrm{Nml}$ biogas/g VS added was owned by the digester which was fed with PS sample (D-PS), while the digester which was fed with Co-Digestion sample (D-CO) had the highest biogas yield (around $499.8 \mathrm{Nml} / \mathrm{g}$ VS added). The biogas yield for the digester that was fed with SHW sample (D-SHW) was nearly $433.8 \mathrm{Nml} / \mathrm{g}$ VS added.

For methane yield, it can be seen that D-CO had the highest methane yield at $220.3 \mathrm{Nml}-\mathrm{CH}_{4} / \mathrm{g} \mathrm{VS}$ added, while D-SHW had the lowest methane yield at $186.9 \mathrm{Nml}_{-} \mathrm{CH}_{4} / \mathrm{g}$ VS added. D-PS had the mid value for methane yield at $200.1 \mathrm{Nml}-\mathrm{CH}_{4} / \mathrm{g}$-VS added. Accumulative of methane yield is depicted in Figure 6. 
The Co-digestion system helped in increasing the productivity of gas yield compared with gas yield from digest of the PS and SHW. Using Co-digestion contributed to enhance the activity of the biomass involved in the anaerobic digestion process. The Co-digestion enhanced the carbon-nitrogen ratio as SHW is characterized with high nitrogen content due to blood. It played a role in dilution of the toxic compounds like organic-nitrogen, ammonia, VFA and other intermediate products; those can inhibit the bacteria cells within the digester. This conclusion is in line with Mata-Alvarez et al. 2000 [9].

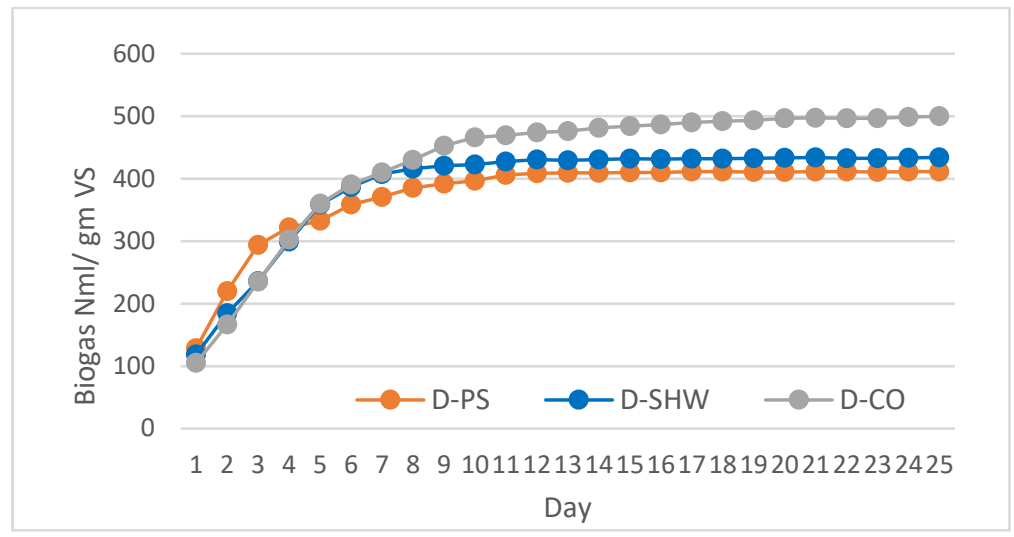

Figure 5. Accumulated biogas production versus time

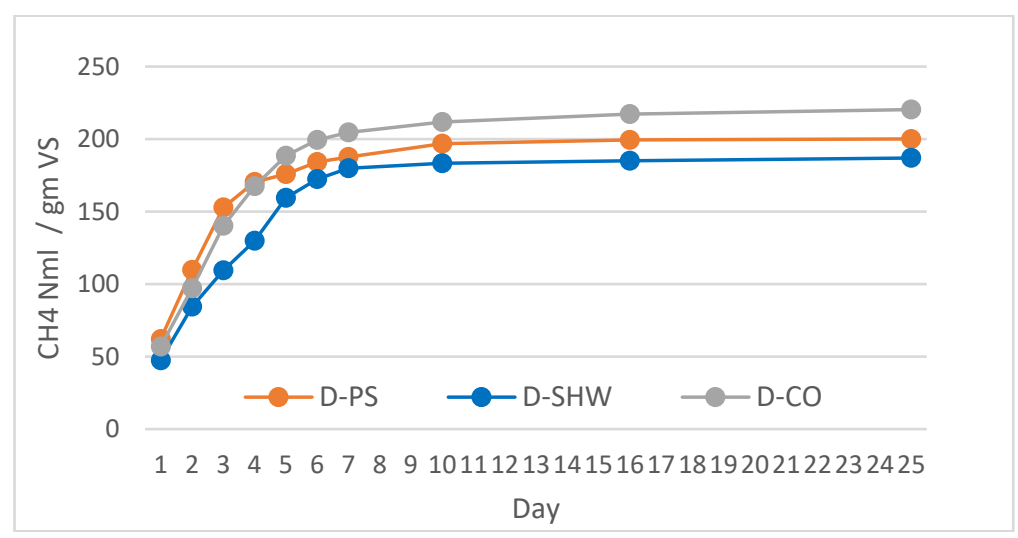

Figure 6. Accumulated $\mathrm{CH}_{4}$ production versus time

The factor responsible for the lower methane production from SHW compared with PS is ammonia. It is produced from degradation of organic nitrogen and protein compounds, especially in blood. It is toxic to methanogenic culture and can cause failure in digestion process [10].

Sulfate Reducing Bacteria competes with methanogenesis in consuming $\mathrm{H}_{2}$ during the digestion process. This type of bacteria reduce sulfate to hydrogen sulfide $\left(\mathrm{H}_{2} \mathrm{~S}\right)$ during digestion. The existing amount of sulphate is produced from protein in blood. The production of hydrogen sulfide has an inhibitory effect on methanogenic bacteria even at low concentrations [11], [12].

Accumulation of VFA in digest causes inhibition to methanogenesis that can lead to lower methane production. This situation occurred in D-SHW since the final VFA concentration was more than the initial concentration.

Clear evidence on production of the toxic gases $\mathrm{H}_{2} \mathrm{~S}$ and $\mathrm{NH}_{3}$ is the disgusting smell when the digestate was withdrawn from the D-SHW. It was running in inhibited state where the process is stable, nevertheless gas production was low due to the effect of ammonia, $\mathrm{H}_{2} \mathrm{~S}$ and VFA.

\subsection{Changing in $\mathrm{pH}$}

The $\mathrm{pH}$ value for D-PS before anaerobic digestion was about 6.28, whereas the $\mathrm{pH}$ value for D-SHW was around 6.89 and $\mathrm{pH}$ for $\mathrm{D}-\mathrm{CO}$ was 6.45. D-SHW had the largest $\mathrm{pH}$ value, which was near 7.52. The methanogenesis bacteria are most sensitive to $\mathrm{pH}$ compared to other bacteria that are involved in digestion process. The higher protein concentration in D-SHW content produced ammonia as by-product from its fermentation. This increased the $\mathrm{pH}$ more than the allowable similar to Alvarez et al. 2008, where the accumulation of ammonia resulted from degradation the nitrogen in blood [13]. Growth of methanogensis and methanogenic activity has been disturbed. There was $\mathrm{pH}$ inhibition (partially or fully) in D-SHW, which negatively affected methane production. 
The final $\mathrm{pH}$ of D-PS was 7.27, while $\mathrm{pH}$ of D-CO reached 7.38. Both $\mathrm{pH}$ values for D-PS and D-CO are within optimal methanogenesis range at 6.6 - 7.4 [14]. There are no inhibition effects in D-PS and D-CO during digestion process. The $\mathrm{pH}$ for D-SHW had a value more than the upper limit of optimum methanogenesis ranges. Figure 7 presents the changing in $\mathrm{pH}$ value in each reactor; $\mathrm{pH}$ increased when increasing the $\mathrm{SHW}$ proportion in the reactor.

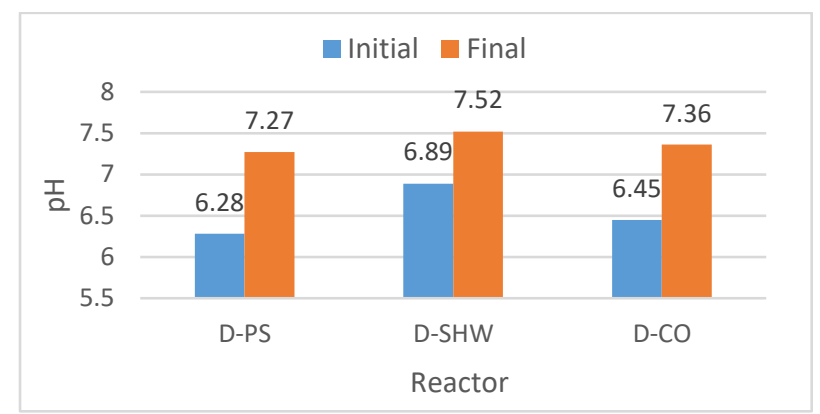

Figure 7. Initial and final $\mathrm{pH}$

Many literatures reported that SHW contains protein, which can be a reason for $\mathrm{pH}$ increasing. The increasing in $\mathrm{pH}$ value in D-SHW is contributed to production of alkaline compounds during the degradation of organics in the digester such as ammonium ions. The alkalinity buffer and VFA kept within accepted range as the $\mathrm{pH}$ of the digester is directly related with the concentration of the produced VFA and the bicarbonate alkalinity.

Using PS helped to maintain the $\mathrm{pH}$ value within the optimum range. This agrees with Hills and Roberts, 1981, who applied Co-digestion to adjust the $\mathrm{pH}$ value within the optimum range rather than using the chemical treatment methods [15].

\subsection{Organic acid}

The final VFA was less than the initial concentration in D-PS and D-CO. The VFA was consumed for specific degree within the digestion system. For D-SHW, at final day, VFA concentration was higher than the first day. This is a clear indication for accumulation of VFA within the digester media. VFA value declined more than $33 \%$ to $72 \%$ in D-CO and D-PS respectively. It increased by $42 \%$ in D-SHW (Figure 8 ).

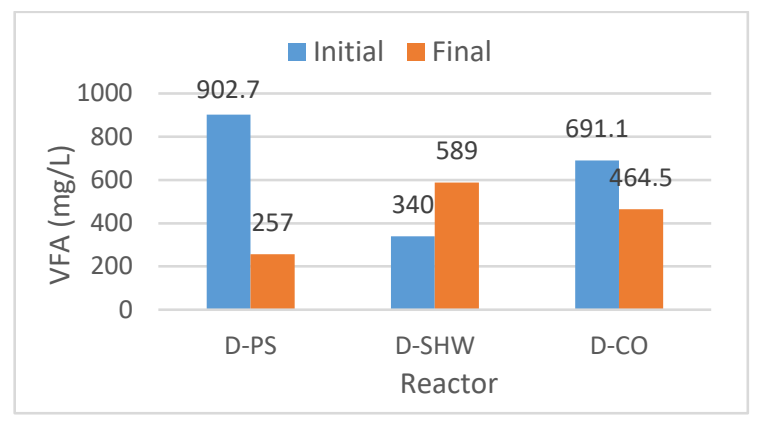

Figure 8. Initial and final VFA concentration.

Most produced acids were consumed in D-PS, and D-CO, while the acid concentration increased in D-SHW. Due to VFA accumulation, methanogens is not able to transform the acetates and lowering methane production for D-SHW. There was a high concentration of ammonia nitrogen within the system causing an increase in alkalinity. Alkalinity maintained $\mathrm{pH}$ despite VFA accumulation and $\mathrm{pH}$ did not drop in D-SHW despite the accumulation of the acids. This agrees with Padilla et al. 2011 [16].

\section{Conclusions}

1) Co-digestion of SHW with PS had increased biogas yield (Nml Biogas per g VS fed) and had increased methane yield for both individually when SHW and PS were digested separately.

2) Methane gas is quite possible to be obtained from SHW, but digesting it in solo digestion system will lead to methanogenesis inhibition. Addition of PS help to minimize the limitation of digest SHW. Biogas production can be increased by minimizing SHW in Co-digestion mixture.

3) Co-digesting PS with SHW is a suitable strategy to increase biogas production in WWTP Nablus-West [17]. 


\section{Acknowledgement}

The authors thank Prof. Dr. Marwan Haddad of the Water and Environmental Studies Institute, An-Najah National University for supervising and providing the scholarship under the Palestinian-Dutch Academic Cooperation Program on Water (PADUCO) and allowing this research to be undertaken. Thanks are extended to the colleagues from the WWTP Nablus-West.

\section{References}

[1] Ostrem K. Greening waste: anaerobic digestion for treating the organic fraction of municipal solid wastes [M.S. thesis]. New York, U.S.A.: Columbia University; 2004.

[2] Iacovidou E, Ohandja DG, Voulvoulis N. Food waste co-digestion with sewage sludge-realising its potential in the UK. Journal of environmental management. 2012;112:267-274.

[3] Kelley TR, Walker PM. Bacterial concentration reduction in swine waste amended livestock feed using a single-screw dry-extrusion process. Bioresource technology. 2000;75(3):189-195.

[4] Wellinger A, Lindberg A. Biogas upgrading and utilisation. IEA Bioenergy. Task 24: Energy from biological conversion of organic waste, 1999.

[5] Bayr S, Rantanen M, Kaparaju P, Rintala J. Mesophilic and thermophilic anaerobic co-digestion of rendering plant and slaughterhouse wastes. Bioresource technology. 2012;104:28-36.

[6] Serrano A, Ángel Siles López J, Chica AF, Martin M, Karouach F, Mesfioui A, El Bari H. Mesophilic anaerobic co-digestion of sewage sludge and orange peel waste. Environmental technology. 2014;35(7):898906.

[7] APHA-AWWA-WEF. Standard methods for the examination of water and wastewater, 20th edition. American Public Health Association, American Water Works Association and Water Environment Federation, New York, NY;1998.

[8] Guo M. Life cycle assessment (LCA) of light weight eco-composites. S.L. Springer; 2016.

[9] Mata-Alvarez J, Mace S, Llabres P. Anaerobic digestion of organic solid wastes. An overview of research achievements and perspectives. Bioresource technology. 2000;74(1):3-16.

[10] Wang Z, Banks CJ. Evaluation of a two-stage anaerobic digester for the treatment of mixed abattoir wastes. Process Biochem. 2003; 38(9): 1267-1273.

[11] Gerardi MH. The microbiology of anaerobic digesters. John Wiley \& Sons; 2003.

[12] Alvarez R, Lidén G. Semi-continuous co-digestion of solid slaughterhouse waste, manure, and fruit and vegetable waste. Renewable Energy. 2008; 33(4): 726-734.

[13] Moosbrugger RE, Wentzel MC, Loewenthal RE, Ekama GA, Marais GVR. Alkalinity measurement: Part 3A5 $\mathrm{pH}$ point titration method to determine the carbonate and SCFA weak acid/ bases in aqueous solution containing also known concentrations of other weak acid/bases. Water SA. 1993;19 (1):29-40.

[14] Gomec YC, Speece RE. The role of $\mathrm{pH}$ in the organic material solubilisation of domestic sludge in anaerobic digestion. Water Sci. technol. 2003; 48:143-150.

[15] Hills DJ, Roberts DW. Anaerobic digestion of dairy manure and field crops residues. Agric Wastes. 1981; 3:179-189.

[16] Padilla E, López A, Gallardo J. Evaluation of stability factors in the anaerobic treatment of slaughterhouse wastewater. J Bioremed Biodegrad. 2011; 2:114.

[17] Dababat, S. Enhancing biogas production by using slaughterhouse wastewater and domestic sludge to cover energy demand for wastewater treatment plant in Nablus [MSc. Thesis]. Nablus, Palestine: Faculty of Graduate Studies, An-Najah National University; 2017.

(C) 2019 by the author(s). This work is licensed under a Creative Commons Attribution 4.0 International License (http://creativecommons.org/licenses/by/4.0/). Authors retain copyright of their work, with first publication rights granted to Tech Reviews Ltd. 